\title{
Human Anti-Idiotype Antibody
}

National Cancer Institute

\section{Source}

National Cancer Institute. Human Anti-Idiotype Antibody. NCI Thesaurus. Code C129918.

A human anti-mouse antibody that binds to the antigen-combining site of another antibody. 